\title{
Identification of Coiled-Coil Domain-Containing Protein 180 and Leucine-Rich Repeat-Containing Protein 4 as Potential Immunohistochemical Markers for Liposarcoma Based on Proteomic Analysis Using Formalin-Fixed, Paraffin-Embedded Tissue
} Check for updates

Tomoyuki Aoyama, ${ }^{* \dagger}$ Akira Takasawa, ${ }^{*}$ Kumi Takasawa, ${ }^{*}$ Yusuke Ono, ${ }^{*}$ Makoto Emori, ${ }^{\ddagger}$ Masaki Murata, ${ }^{*}$ Takahiro Hayasaka, Naoki Fujitani, ${ }^{\top}$ Makoto Osanai, ${ }^{*}$ Toshihiko Yamashita, ${ }^{\ddagger}$ Tadashi Hasegawa, ${ }^{\dagger}$ and Norimasa Sawada*

From the Departments of Pathology, ${ }^{*}$ Surgical Pathology, ${ }^{\dagger}$ Orthopedic Surgery, ${ }^{\ddagger}$ and Biochemistry, ${ }^{\llbracket}$ Sapporo Medical University School of Medicine, Sapporo; and the Department of Gastroenterological Surgery I, ${ }^{\S}$ Hokkaido University Graduate School of Medicine, Sapporo, Japan

\author{
Accepted for publication \\ January $24,2019$. \\ Address correspondence to \\ Akira Takasawa, M.D., Ph.D., \\ Department of Pathology, Sap- \\ poro Medical University School \\ of Medicine, S1 W17, Chuo-ku, \\ Sapporo 060-8556, Japan. E- \\ mail: atakasawa@sapmed.ac.jp.
}

\begin{abstract}
Recent technical improvements in both mass spectrometry and protein extraction have made it possible to use formalin-fixed, paraffin-embedded (FFPE) tissues for proteome analysis. In this study, comparable proteome analysis of FFPE tissues revealed multiple candidate marker molecules for differentiating atypical lipomatous tumor/well-differentiated liposarcoma (ALT/WDL) from lipoma. A total of 181 unique proteins were identified for ALT/WDL. Of the identified proteins, coiled-coil domain-containing protein 180 (CCDC180) and leucine-rich repeat-containing protein 4 (LRRC4) were studied as candidate markers of ALT/WDL. CCDC180 and LRRC4 immunohistochemistry clearly stained tumor cells of ALT/WDL and dedifferentiated liposarcoma and could differentiate them from lipoma with high accuracy. Cell biological methods were used to further examine the expression of the candidate marker molecules in liposarcoma cells. In liposarcoma cells, knockdown of CCDC180 and LRRC4 inhibited cell proliferation. CCDC180 inhibited cell migration, invasion, and apoptosis resistance in WDL cells. Adipogenic differentiation suppressed the expression of CCDC180 and LRRC4 in WDL cells. These results indicated that LRRC4 and CCDC180 are novel immunohistochemical markers for differentiating ALT/WDLs. Their expression was associated with adipocyte differentiation and contributed to malignant potentials of WDL cells. Proteome analysis using a standard stock of FFPE tissues can reveal novel biomarkers for various diseases, which contributes to the progress of molecular pathology. (Am J Pathol 2019, 189: 1015-1028; https://doi.org/10.1016/j.ajpath.2019.01.013)
\end{abstract}

Proteomics is the large-scale analysis of a proteome, a data set of total proteins in a biological system including their amount, cellular structure, and function. Every alteration of proteins directly reflects some biological or clinical events and can become an important factor of pathologic abnormality. Recently, mass spectrometry (MS)-based proteomics has been used to discover biomarkers for a variety of diseases as well as to elucidate molecular mechanisms. ${ }^{1-5}$ In comparison with mRNA-based analytical methods, MS-based proteomics has the advantage of enabling discovery of immunohistochemical markers because immunohistochemistry is based on the detection of proteins. ${ }^{6}$

Supported by JSPS KAKENHI grants JP16K21250 (T.A.), JP16K08693 (N.S.), JP26460421 (A.T.), and JP17K08698 (A.T.), and JP17K08697 (M.O.), and the Kurozumi Medical Foundation (A.T.).

Disclosures: None declared. 
Formalin-fixed, paraffin-embedded (FFPE) tissues are archived in a hospital to be generally prepared for histopathological examination with hematoxylin and eosin staining and immunohistochemistry. FFPE tissues can be stored for a long period, resulting from rigid cross-linking of molecular components by formaldehyde. Long-term preserved FFPE tissues are the best source for retrospective studies because they are stocked along with detailed information about patients, including clinicopathological features, blood test results, outcome, response to therapy, and adverse events. ${ }^{7,8}$ On the other hand, the preservative advantage has inversely prevented FFPE tissues from being used for some biochemical analyses other than immunohistochemistry because of the difficulty in extraction of a sample with high quality. However, recent technical improvements in mass spectrometry and protein extraction have made it possible to use FFPE tissues for proteome analysis, ${ }^{9-11}$ resulting in identification of novel biomarkers for pancreatic cancer, ${ }^{12,13}$ rheumatoid arthritis, ${ }^{14}$ and colorectal cancer. ${ }^{15}$

Lipomatous tumors represent the largest single group of mesenchymal tumors, including benign-type lipoma and malignant liposarcoma. ${ }^{16}$ Among the liposarcomas, atypical lipomatous tumor/well-differentiated liposarcoma (ALT/ WDL) represents the largest subgroup and is similar to benign lipoma in histologic appearance. In clinical pathology, it is important to differentiate ALT/WDL from lipoma because ALT/WDL can proceed on to dedifferentiation, a critical risk factor for distant metastasis. Genomic PCR and fluorescence in situ hybridization, for detecting amplification of chromosome 12q13-q15 in ALT/WDL, are helpful for differential diagnosis, although those analyses are not appropriate for clinical practice everywhere. Overexpressions of E3-ubiquitin-protein ligase Mdm2 (MDM2), cyclin-dependent kinase 4 (CDK4), and highmobility group protein, which result from 12q13-q15 amplification, are also used as ALT/WDL markers in immunohistochemistry. ${ }^{16-22}$ However, immunohistochemistry of the molecules has limited applicability to practical use because of the small number of immunopositive cells in specimens. Therefore, useful immunohistochemical markers are required to distinguish ALT/WDL from lipoma.

In this study, comparable proteome analysis of FFPE tissues revealed multiple candidate marker molecules for differentiating ALT/WDL from lipoma. It was also confirmed that identified molecules, coiled-coil domain-containing protein $180(\mathrm{CCDC} 180)$ and leucine-rich repeat-containing protein 4 (LRRC4), were useful in immunohistochemistry. In addition, it was demonstrated that they contributed to malignant roles of WDL cells and that they were up-regulated in association with dedifferentiation.

\section{Materials and Methods}

\section{Materials}

Dithiothreitol, iodoacetamide, ammonium bicarbonate, acetonitrile, ethanol, guanidine hydrochloride (guanidine$\mathrm{HCl}$ ), hydrochloric acid, formic acid, dexamethasone, and cisplatin were purchased from Wako (Osaka, Japan). Heptane, methanol, acetic acid, and chloroform were purchased from Kanto Chemical (Tokyo, Japan). 3-Isobutyl-1methylxanthine, oleic acid, trifluoroacetic acid (TFA), and trypsin were purchased from Sigma-Aldrich (St. Louis, MO). The Qproteome FFPE tissue kit was purchased from Qiagen (Hilden, Germany). Antibodies used in this study are listed in Table 1.

\section{Patient Samples}

The present research protocol was approved by the Sapporo Medical University Ethics Committee (Sapporo, Japan), and informed consent was obtained from all participating

Table 1 List of Antibodies Used in This Study

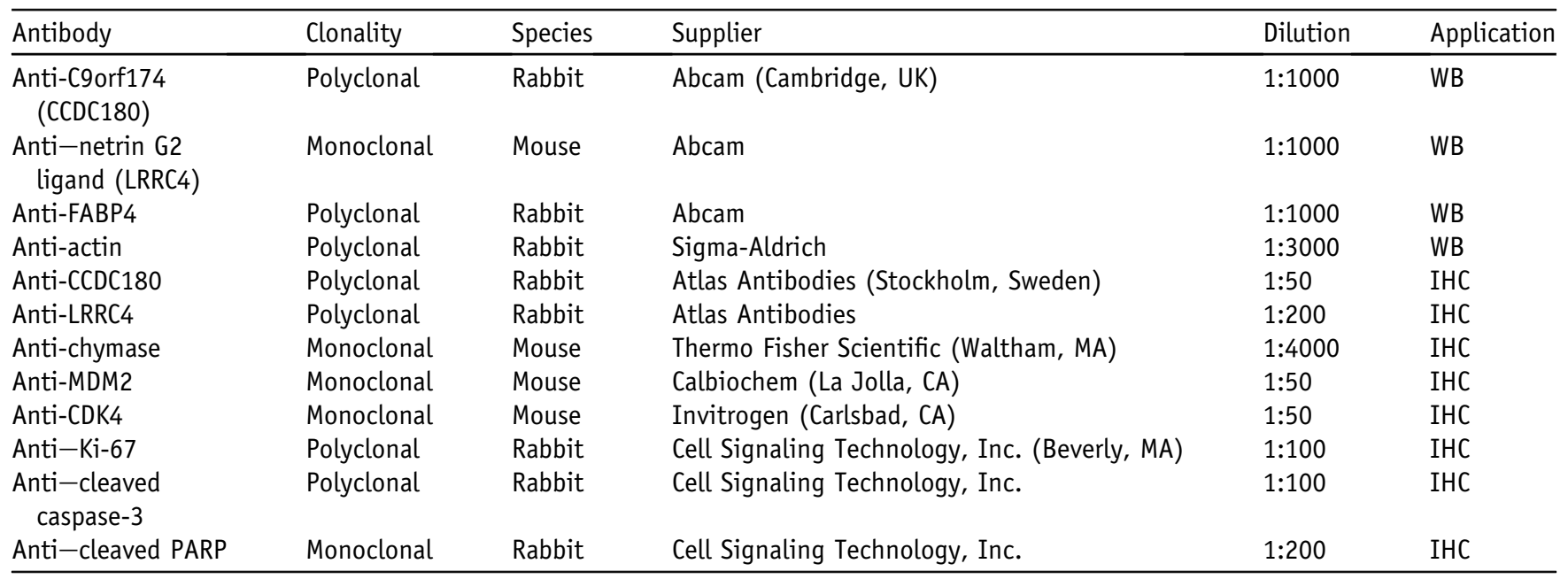

CDK4, cyclin-dependent kinase 4; FABP4, fatty acid-binding protein 4; IHC, immunohistochemistry; MDM2, E3-ubiquitin-protein ligase Mdm2; PARP, poly (ADP-ribose) polymerase; WB, Western blot analysis. 
patients. The tissues used in this study were from 47 patients who underwent surgical resection for ALT/WDL, dedifferentiated liposarcoma (DDL), or lipoma at Sapporo Medical University Hospital (Sapporo, Japan) during the period from 2006 to 2017. FFPE tissue blocks from 22 cases of ALT/ WDL, 18 cases of DDL, and 25 cases of lipoma were obtained from the pathology file of Sapporo Medical University Hospital. Clinicopathological features of the patients are summarized in Supplemental Table S1. After detailed histopathological analysis, 4 of 22 ALT/WDL cases and 4 of 25 lipoma cases were selected for downstream peptide sample preparation.

\section{Peptide Sample Preparation}

Peptide sample preparation was performed, as described before, with some modifications. ${ }^{15,23-25}$ FFPE tissue blocks were divided into sections on a microtome to eight serial sections (10 to $15 \mu \mathrm{m}$ thick and approximately $100 \mathrm{~mm}^{2}$ in size). Each of the FFPE tissue sections was deparaffinized by $0.5 \mathrm{~mL}$ heptane in a $2.0-\mathrm{mL}$ microtube at room temperature for 90 minutes. After adding $25 \mu \mathrm{L}$ of methanol, the tissue was collected by centrifugation. The supernatant was removed, and the pellet was left to dry in air at room temperature. Subsequent protein extraction was performed by using a Qproteome FFPE tissue kit or the guanidine- $\mathrm{HCl}$ method (Figure 1). In cases in which the Qproteome FFPE tissue kit was used, the air-dried tissue pellet was resuspended in $100 \mu \mathrm{L}$ of extraction buffer, briefly sonicated, and incubated at $100^{\circ} \mathrm{C}$ for 20 minutes. It was then incubated in the tube at $80^{\circ} \mathrm{C}$ for 2 hours with agitation and centrifugation $\left(14,000 \times g\right.$ for 15 minutes at $\left.4^{\circ} \mathrm{C}\right)$. After cooling, the supernatant was collected in a new microtube. To purify the protein sample, $400 \mu \mathrm{L}$ of methanol, $100 \mu \mathrm{L}$ of chloroform, and $300 \mu \mathrm{L}$ of water were added to each tube in turn, followed by vortex mixing for 10 seconds and centrifugation. After removal of the upper layer, the protein was formed as a white gel-like pellet on the bottom of the tube when centrifuged after adding $300 \mu \mathrm{L}$ of methanol. After washing the pellet with ethanol and centrifugation, the pellet was dissolved in 20 $\mu \mathrm{L}$ of $\beta$-ME Sample Treatment (Cosmo Bio, Tokyo, Japan). The protein samples were applied to $4 \%$ to $20 \%$ gradient SDS polyacrylamide gel (Cosmo Bio) and electrophoresed to stack the protein into the gel until the dye front reached to $5 \mathrm{~cm}$ below the bottom of the sample-loaded well. The proteinstacked gels were excised, and the gels were further divided into approximately 1-mm square cubes. After reduction and alkylation, in-gel digestion was performed with trypsin overnight at $37^{\circ} \mathrm{C}$, as described by Shevchenko et al. ${ }^{26} \mathrm{In}$ cases in which the guanidine- $\mathrm{HCl}$ method was used to extract proteins from the pellet, the dried material was resuspended in $250 \mu \mathrm{L}$ of $6 \mathrm{~mol} / \mathrm{L}$ guanidine- $\mathrm{HCl} / 50 \mathrm{mmol} / \mathrm{L}$ ammonium

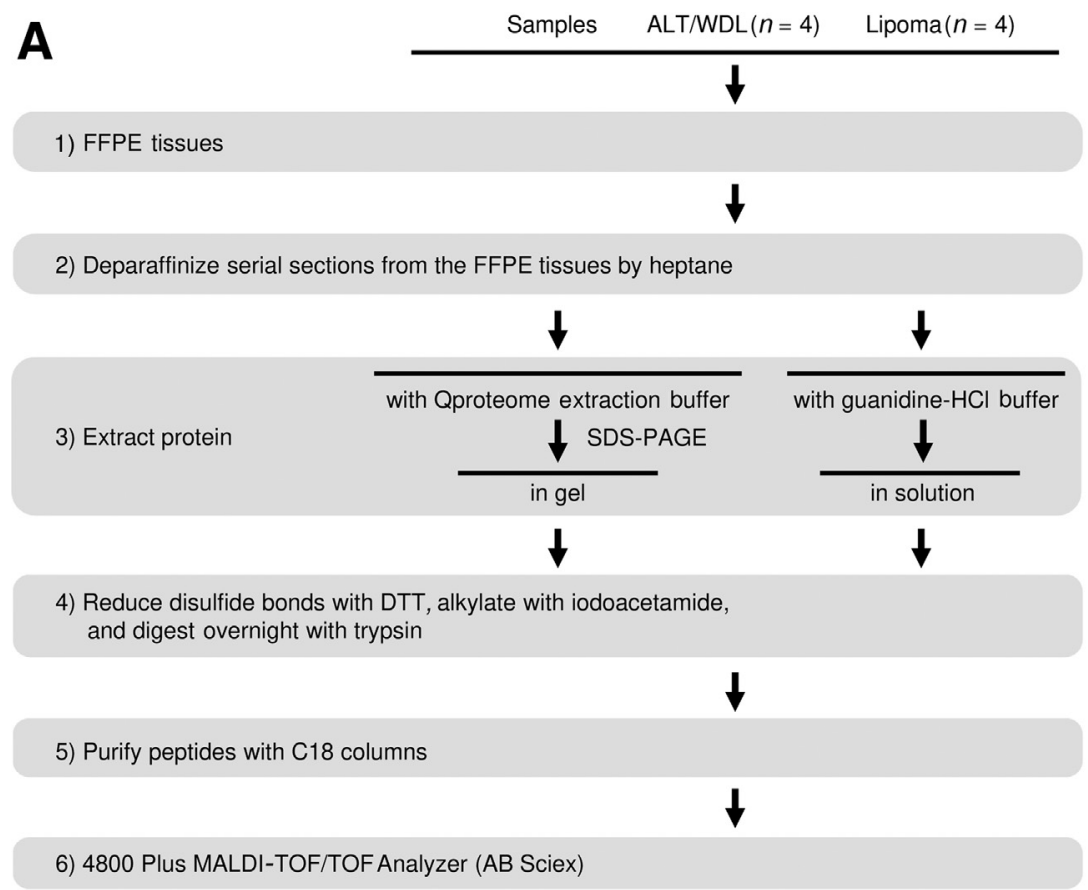

B

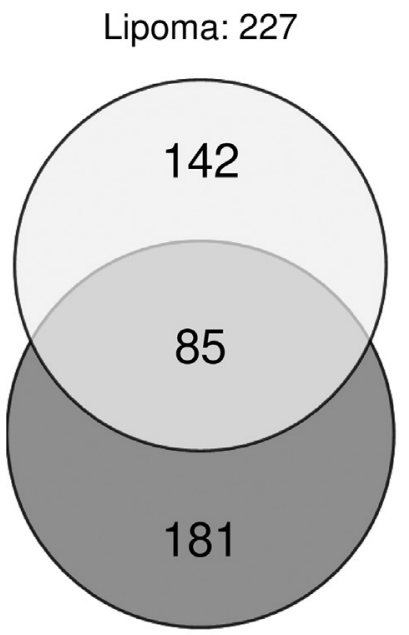

ALT/WDL: 266

Figure 1 Comparable proteome analysis of atypical lipomatous tumor/well-differentiated liposarcoma (ALT/WDL) and lipoma formalin-fixed, paraffinembedded (FFPE) tissues. A: Experimental workflow. 1) FFPE tissue specimens were obtained, 2) eight serial sections (10 to $15 \mu \mathrm{m}$ thick and approximately 100 $\mathrm{mm}^{2}$ in size) from FFPE tissues were deparaffinized by heptane in a microtube, 3) subsequent protein extraction was performed by using a Qproteome FFPE tissue kit or guanidine-HCl method, 4) disulfide bonds were reduced with dithiothreitol (DTT) and alkylated with iodoacetamide, and the sample was digested overnight with trypsin, 5) peptides were purified, and 6) matrix-assisted laser desorption/ionization-time-of-flight/time-of-flight (MALDI-TOF/TOF) analysis was performed. B: Venn map of proteins that were identified by mass spectrometry-based global proteomic analysis from ALT/WDL and lipoma of FFPE tissues (Unused ProtScore $>0.15$ ). 
Table 2 List of siRNAs Used in This Study

\begin{tabular}{lll}
\hline Name of siRNA & Gene & Sequence of siRNA \\
\hline siCCDC\#1 & CCDC180 & $5^{\prime}$-GCCAAUACUUCUUUGUGCGUGAAAU-3' \\
SiCCDC\#2 & $C C D C 180$ & $5^{\prime}$-GGUUGCUGACGAAUCUGCAAGUGAA-3' \\
SiLRRC\#1 & LRRC4 & $5^{\prime}$-CUGGUUACCAGCCGGCAUA-3' \\
SiLRRC\#2 & LRRC4 & $5^{\prime}$-GUAUAUCUCUGAGGGAGCU-3' \\
\hline
\end{tabular}

bicarbonate $/ 20 \mathrm{mmol} / \mathrm{L}$ dithiothreitol ( $\mathrm{pH} 8.5$ ), briefly sonicated, and incubated at $100^{\circ} \mathrm{C}$ for 20 minutes and then incubated in the tube at $80^{\circ} \mathrm{C}$ for 2 hours with agitation. After cooling, the recovered proteins were quantified with a Pierce BCA Protein Assay kit (Thermo Fisher Scientific, Waltham, MA). Iodoacetamide was added to a final concentration of 40 $\mathrm{mmol} / \mathrm{L}$, and the sample was incubated at room temperature in the dark for 1 hour. The alkylation reaction was quenched by adding $3 \mu \mathrm{L}$ of $2 \mathrm{~mol} / \mathrm{L}$ dithiothreitol. For tryptic digestion, the sample was diluted (1:6) with $50 \mathrm{mmol} / \mathrm{L}$ ammonium bicarbonate $(\mathrm{pH} 8.1)$ to reduce the concentration of guanidine- $\mathrm{HCl}$ buffer (final concentration of $1 \mathrm{~mol} / \mathrm{L}$ ) and digested with trypsin overnight. After digestion, the mixture was acidified with TFA (final concentration of $0.1 \%$ ). To remove interfering substances before mass spectrometry, the mixture was desalted with MonoSpin C18 (GL Sciences, Tokyo, Japan), according to the manufacturer's instructions. Finally, peptides were eluted with $0.1 \%$ formic acid in $60 \%$ acetonitrile and stored at $-20^{\circ} \mathrm{C}$ until analysis.

\section{Mass Spectrometry}

Peptides were subsequently separated on a HiQsilC18W-3 column $(100 \mu \mathrm{m}$ inner diameter $\times 100$; KYA Technology, Tokyo, Japan), according to a previous report. ${ }^{25}$ Elution solvent $\mathrm{A}$ and solvent $\mathrm{B}$ were $0.1 \%$ TFA and $0.1 \%$ TFA, respectively, in $70 \%$ acetonitrile. The gradient was $5 \%$ to $50 \%$ for solvent B over 50 minutes at a flow rate of $300 \mathrm{~nL} /$ minute. Separated peptides were spotted onto 384-well AB OptiTOF MALDI Plate Inserts (AB Sciex, Foster City, CA). The 150-nL peptide fractions were overlaid with $700 \mathrm{~nL}$ aCHCA (Sigma, Tokyo, Japan) in $80 \mathrm{mg} / \mathrm{mL}$ ammonium citrate, $70 \%$ acetonitrile, and $0.1 \%$ TFA. A 4800 Plus MALDI-TOF/TOF Analyzer (AB Sciex), with 4000 Series Explorer version 3.5 software (AB Sciex), was used for mass spectrometric analyses. The mass accuracy was calibrated by using tryptic bovine serum albumin standard (KYA Technology) and a six-peptide mixture (AB Sciex). MS/MS acquisitions of MS spectra with signal to noise ratio $>100$ were performed using air as the collision gas with a collision energy of $1 \mathrm{kV}$. Peptide tolerance was $100 \mathrm{ppm}$, and MS/MS tolerance was 1 Da. Data were processed by Protein Pilot version 3.0 (AB Sciex, Framingham, MA) using the Paragon search algorithm. ${ }^{27}$ MS/MS data were searched against the human International Protein Index database version 3.63 (European Bioinformatics Institute, Cambridgeshire, UK). The Unused ProtScore reflects the total amount of unique peptide evidence related to a given protein.

\section{Immunohistochemistry of Surgical Specimens}

Specimens of 22 cases of ALT/WDL, 18 cases of DDL, and 25 cases of lipoma, obtained by surgical resections during the period from 2006 to 2017, were retrieved from the pathology file of Sapporo Medical University Hospital. The hematoxylin and eosin slides of all cases were reviewed to select representative sections. New sections from paraffin blocks were examined by the labeled polymer method. Immunohistochemical labeling was visualized using Dako REAL EnVision Detection System (Agilent Technologies, Inc., Santa Clara, CA), as per the manufacturer's protocol. ${ }^{28-30}$ Antigen of CCDC180, LRRC4, chymase, MDM2, and CDK4 retrieval was performed by immersing sections in 10 $\mathrm{mmol} / \mathrm{L}$ tris/1 mmol/L EDTA buffer $(\mathrm{pH} 9.0)$ or $10 \mathrm{mmol} / \mathrm{L}$ citrate buffer ( $\mathrm{pH}$ 6.0) and boiling them in a microwave $\left(95^{\circ} \mathrm{C}, 30\right.$ minutes), followed by overnight incubation at $4^{\circ} \mathrm{C}$ with antibodies to the following antigens: CCDC180, LRRC4, chymase, MDM2, and CDK4. The intensity of staining was assessed as strong $(3+)$, moderate $(2+)$, weak $(1+)$, or negative $(0)$. All slides were independently evaluated by two pathologists (A.T. and M.M.). Discordant cases were discussed, and a consensus was reached. ${ }^{31}$

\section{Cell Line Culture and Treatment}

The human liposarcoma cell lines 93T449 and SW872 were purchased from ATCC (Manassas, VA). 93T449 cells (derived from well-differentiated liposarcoma) were maintained in RPMI 1640 medium supplemented with $10 \%$ fetal bovine serum (Invitrogen, Carlsbad, CA). SW872 cells were maintained in Dulbecco's modified Eagle's medium (Sigma-Aldrich) supplemented with $10 \%$ fetal bovine serum. The medium for the cell lines contained $100 \mathrm{U} / \mathrm{mL}$ penicillin and $100 \mu \mathrm{g} / \mathrm{mL}$ streptomycin. All cells were plated on 60-mm culture dishes (Corning Glass Works, Corning, NY) and incubated in a humidified $5 \% \quad \mathrm{CO}_{2}$ incubator at $37^{\circ} \mathrm{C}$. $93 \mathrm{~T} 449$ cells were treated with $40 \mathrm{mmol} /$ $\mathrm{L}$ cisplatin for 24 hours.

\section{Induction of Adipocyte Differentiation of 93T449 Cells}

One-day post-confluent 93T449 cells were treated with an adipogenic cocktail containing $0.5 \mathrm{mmol} / \mathrm{L}$ 3-isobutyl-1methylxanthine and $0.25 \mu \mathrm{mol} / \mathrm{L}$ dexamethasone. After 4 days, the medium was replaced with fresh Dulbecco's modified Eagle's medium supplemented with $8 \%$ fetal bovine serum containing $100 \mu \mathrm{mol} / \mathrm{L}$ oleic acid, and the medium was 
replaced every 2 to 3 days for 21 days. Cells were harvested for Western blot analysis or examined by using Oil Red O staining (Wako Pure Chemical Industries, Ltd, Osaka, Japan). Cells in 60-mm culture dishes were washed with phosphate-buffered saline, fixed with $10 \%$ formalin neutral buffer solution for 5 minutes, incubated with $0.3 \%$ (w/v) Oil Red O in $60 \%$ (v/v) isopropanol for 30 minutes at room temperature, and washed with distilled water. Fat droplets in the adipogenesis-induced cells were evaluated with a phase-contrast microscope. ${ }^{32}$

\section{Gene Silencing Using siRNA}

siRNA targeting the mRNA sequences of human CCDC180 or LRRC4 and siRNA universal negative control were purchased from Sigma-Aldrich. Transfection of siRNA was performed using RNAiMAX Transfection Reagent (Invitrogen), according to the manufacturer's instructions. siRNAs used in this study are listed in Table 2.

\section{Immunohistochemistry of Cell Block}

Cell blocks were prepared by using the sodium alginate method. ${ }^{28}$ Briefly, cells were collected in a $2.0-\mathrm{mL}$ tube and washed with phosphate-buffered saline. Supernatant was discarded after centrifugation, and cells were fixed in $10 \%$ formalin solution for 12 to 24 hours at $4^{\circ} \mathrm{C}$. Fixative was discarded after centrifugation, and aggregated cells were gently suspended in $1 \%$ sodium alginate solution (Wako Pure Chemical Industries, Ltd). Then, $1 \mathrm{~mol} / \mathrm{L} \mathrm{CaCl}_{2}$ was added to form gel, and the fixed cell-containing gel was embedded in paraffin. Thin sections $(4 \mu \mathrm{m}$ thick) were cut from paraffin-embedded cell blocks and stained with hematoxylin and eosin. Deparaffinized sections were immersed in $10 \mathrm{mmol} / \mathrm{L}$ sodium citrate buffer ( $\mathrm{pH} \mathrm{6.0)}$ and autoclaved for antigen retrieval. Primary antibodies were anti-Ki-67 or cleaved caspase-3. Immunohistochemical labeling was visualized using the EnVision system, as per the manufacturer's protocol. ${ }^{28,29}$

\section{RNA Isolation}

RNA isolation and RT-PCR were performed, as described previously. ${ }^{33}$ Primers used for RT-PCR of CCDC180 and LRRC4 are listed in Table 3.

\section{Western Blot Analysis}

Western blot analysis was performed, as described previously. ${ }^{34}$ Immunoreactive bands were detected by the Clarity
Western electrochemiluminescence substrate system (BioRad Laboratories, Hercules, CA) using AE-9300H EzCapture MG (ATTO, Tokyo, Japan). Densitometry was performed on immunoblot images using ImageJ software version $1.45 \mathrm{~s}$ (NIH, Bethesda, MD; https://imagej.nih.gov/ij). ${ }^{35}$

\section{Plate Colony-Forming Assay}

Cells were seeded in 6-well plates at a density of 2500 cells per well. After incubation for 10 to 14 days, cells were washed with phosphate-buffered saline twice, fixed with methanol for 15 minutes, and stained with $0.04 \%$ crystal violet for $15 \mathrm{mi}-$ nutes at room temperature. The colony is defined to consist of at least 50 cells. Visible colonies were counted. Each experiment was independently repeated six times. ${ }^{36}$

\section{Cell Proliferation Assay}

A WST-8 assay (Dojindo Laboratories, Kumamoto, Japan) was performed, as described previously. ${ }^{37}$ Cells were seeded in 96-well plates, and its viability was assessed at 24 hours after incubation by using the Cell Counting Kit- 8 (Dojindo Laboratories), according to the manufacturer's instructions. Absorbance at a wavelength of $450 \mathrm{~nm}$ was measured by using a Bio-Rad model 680 microplate reader (Bio-Rad Laboratories).

\section{Cell Migration and Invasion Assay}

A cell migration and invasion assay was performed, as described previously. ${ }^{37}$ The migration assay was performed using Transwell (Corning Glass Works; 8- $\mu \mathrm{m}$ pore polycarbonate membrane insert) in 24-well dishes. Biocoat Matrigel (Corning Glass Works; pore size, $8-\mu \mathrm{m}$ ) was used to evaluate cell invasion potential. Migrated or invaded cells on the lower side of the filters were examined and counted under a microscope (Olympus, Tokyo, Japan).

\section{Statistical Analysis}

The measured values are presented as means $\pm \mathrm{SD}$. The statistical significance of differences was evaluated using the unpaired two-tailed $t$-test, the $U$-test, the Fisher exact test, and the Kruskal-Wallis test. Statistical significance was accepted when $P<0.05$. All statistical analyses were performed with EZR (Saitama Medical Center, Jichi Medical University, Saitama, Japan), a graphical user interface for R 2.13.0 (R Foundation for Statistical Computing, Vienna, Austria). More precisely, EZR

Table 3 List of Primers Used for RT-PCR

\begin{tabular}{llll}
\hline Gene & Forward primer & Reverse primer & Product size, bp \\
\hline CCDC180 & 5'-AAGAAGGCTGTACCCAGTGC-3' $^{\prime}$ & $5^{\prime}$-TCTCCCAGAGGAGGGTCAAG-3' & 192 \\
LRRC4 & $5^{\prime}$-TTCCTTCCGAGATGGAAAGAGG-3' & $5^{\prime}$-GCTGCACACAGAATCCACAC-3' & 211 \\
GAPDH & $5^{\prime}$-ACCACAGTCCATGCCATCAC-3' & $5^{\prime}$-TCCACCACCCTGTTGCTGTA-3' & 452 \\
\hline
\end{tabular}


is a modified version of $\mathrm{R}$ commander version $1.6-3,{ }^{38}$ designed to add statistical functions frequently used in biostatistics.

\section{Results}

Comparable Proteome Analysis of ALT/WDL and Lipoma FFPE Tissues

To discover useful molecular markers for differentiating ALT/WDL from lipoma, comparable proteome analysis of FFPE tissues was performed from patients with ALT/WDL and from patients with lipoma. First, protein samples were extracted from FFPE tissues of ALT/WDL (four cases) and lipoma (four cases) in two different ways (Figure 1A) to increase the number of proteins identified at the subsequent analytical step. ${ }^{39}$ The protein samples were enzymatically processed into peptide fragments and then the peptide samples were examined by a matrix-assisted laser desorption/ ionization-time-of-flight/time-of-flight analyzer to obtain mass spectra of the fragmented peptides. The obtained mass data of the peptides were separately analyzed by using ProteinPilot software version 3.0 (AB Sciex) ${ }^{27}$ to identify which proteins existed in each of the 16 samples. By using a Qproteome extraction kit, a total of 605 proteins were identified, and 381 and 307 proteins were identified for the four ALT/WDL cases and four lipoma cases, respectively. In Unused ProtScore of $>0.15$, an indicator of experimental reliability in mass spectrometry, a total of 308 proteins were identified, and 207 and 160 proteins were identified for the four ALT/WDL cases and four lipoma cases, respectively. By using a guanidine- $\mathrm{HCl}$ extraction method, a total of 300 proteins were identified, and 171 and 182 proteins were identified for the four ALT/WDL cases and four lipoma cases, respectively. In Unused ProtScore of $>0.15$, a total of 164 proteins were identified, and 100 and 106 proteins were identified for the four ALT/WDL cases and four lipoma cases, respectively. The identified protein data sets were finally integrated into two groups, ALT/WDL and lipoma, after eliminating duplicate proteins for the two methods.

A total of 408 proteins, including 181 proteins identified only for ALT/WDL (unique proteins for ALT/WDL), 142 proteins identified for lipoma (unique proteins for lipoma), and 85 proteins identified for both of them, were identified in Unused ProtScore of $>0.15$ (Figure 1B). Lipid droplet-associated proteins, including perilipin-1 and a lipid metabolism-associated protein, fatty acid-binding protein $4,{ }^{40-43}$ were identified for both ALT/WDL and lipoma, indicating the validity of the current protocol. Total proteins identified in the comparable proteome analysis are listed in Supplemental Table S2.

In gene ontology (GO) classification by a web-based gene set analysis tool kit, WebGestalt version 2013 (http:// webgestalt.org), ${ }^{44}$ the identified proteins were distributed throughout the cell both in ALT/WDL and lipoma with similar tendencies, indicating that there are no characteristics to distinguish between them in the context of biological process, molecular function, and cellular component (Supplemental Figure S1).

Immunohistochemistry of Candidate Marker Molecules in Surgical Specimens of Liposarcoma and Lipoma

Of the 181 unique proteins for ALT/WDL, 15 molecules were identified in multiple cases and emerged as candidate

Table 4 List of Unique Proteins for ALT/WDL

\begin{tabular}{|c|c|c|c|c|c|c|}
\hline UniProt accession & Protein names & Gene names & $\begin{array}{l}\text { Chromosomal } \\
\text { location }\end{array}$ & $\begin{array}{l}\text { Unused } \\
\text { ProtScore* }\end{array}$ & $\begin{array}{l}\text { Total } \\
\text { ProtScore }^{\dagger}\end{array}$ & $\% \operatorname{Cov}$ \\
\hline P23946 & Chymase $^{\ddagger}$ & CMA1 & $14 q 12$ & 15.74 & 15.74 & 48.58 \\
\hline Q6NZY1 & Tryptase beta 2 protein & TPSB2 & $16 \mathrm{p} 13.3$ & 14.59 & 14.59 & 28.37 \\
\hline Q9BYX7 & Putative $\beta$-actin-like protein 3 & POTEKP & $2 q 21.1$ & 7.70 & 7.70 & 13.60 \\
\hline Q6GMX4 & IGL protein & $I G L$ & $22 q 11.22$ & 6.00 & 6.00 & 16.95 \\
\hline P52926 & HMGI-C $\S$ & HMGA2 & $12 q 14.3$ & 4.00 & 4.00 & 42.20 \\
\hline P02763 & $\alpha$-1-Acid glycoprotein 1 & ORM1 & $9 q 32$ & 2.07 & 2.07 & 11.94 \\
\hline Q9P1Z9 & $\operatorname{CCDC} 180^{\ddagger}$ & CCDC180 & $9 q 22.33$ & 2.00 & 2.00 & 2.02 \\
\hline Q9Y355 & Apolipoprotein A1 & APOA1 & $11 q 23.3$ & 2.00 & 2.00 & 16.42 \\
\hline 095197 & Reticulon-3 & RTN3 & $11 q 13$ & 1.15 & 1.15 & 0.89 \\
\hline Q5TEC6 & Histone $\mathrm{H} 3$ & HIST2H3PS2 & $1 q 21.1$ & 0.89 & 6.73 & 36.76 \\
\hline Q8WZ42 & Titin & TTN & $2 q 31.2$ & 0.61 & 0.61 & 0.50 \\
\hline Q9HBW1 & $\mathrm{LRRC}^{\ddagger}$ & $L R R C 4$ & $7 q 32.1$ & 0.28 & 0.28 & 3.22 \\
\hline Q15149 & Plectin & PLEC & $8 q 24.3$ & 0.25 & 0.25 & 1.46 \\
\hline Q9BX59 & Tapasin-related protein & TAPBPL & $12 p 13.31$ & 0.24 & 0.24 & 1.92 \\
\hline Q960W8 & DJ576K7.1 & FRAP1 & $1 q 36.22$ & 0.19 & 0.19 & 2.91 \\
\hline
\end{tabular}

*Unused ProtScore indicates the amount of total, unique peptide evidence related to a given protein.

†Total ProtScore indicates the sum of all peptide evidence related to a given protein.

${ }^{\ddagger}$ Selected proteins as candidate marker molecules.

${ }^{\S}$ A known ALT/WDL marker.

\%Cov, percentage of matching amino acids from identified peptides; ALT, atypical lipomatous tumor; HMGI-C, high-mobility group protein; WDL, welldifferentiated liposarcoma. 
A
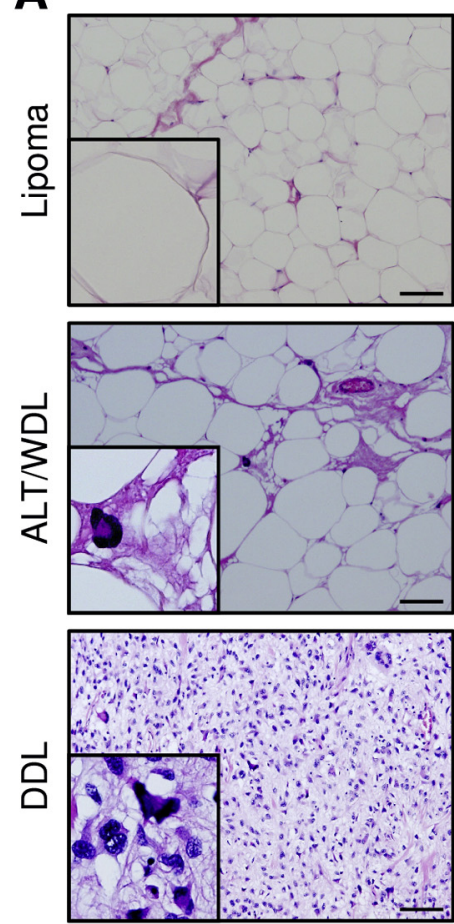

B

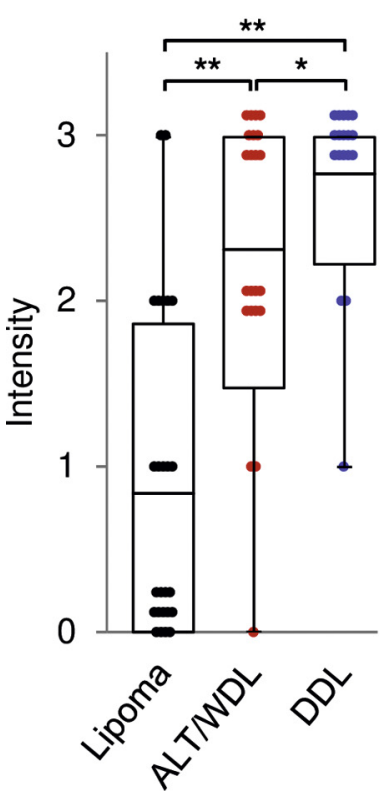

CCDC180
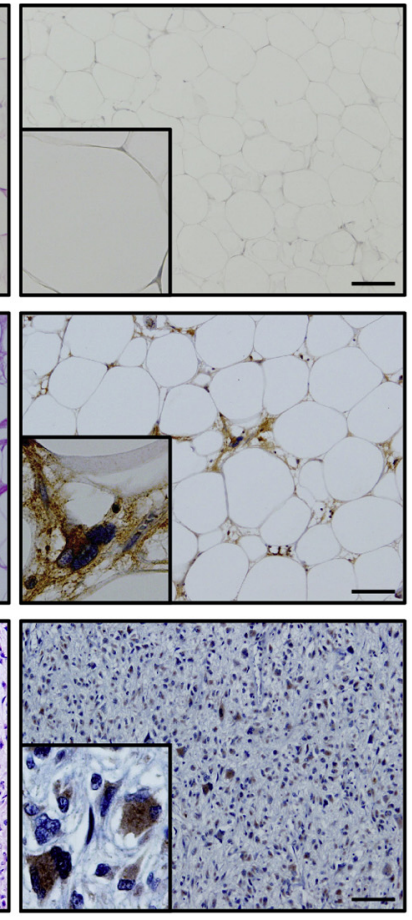

LRRC4

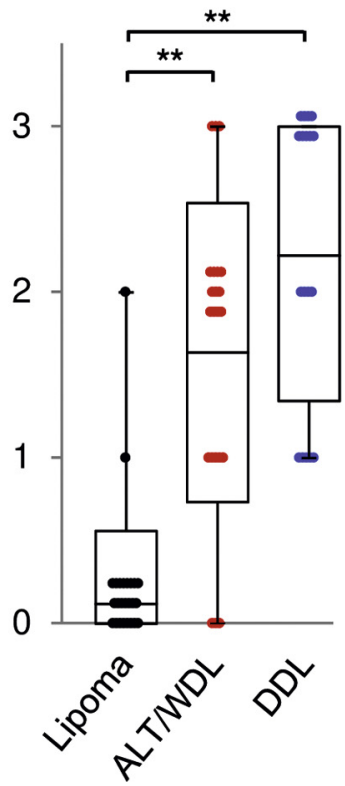

H\&E
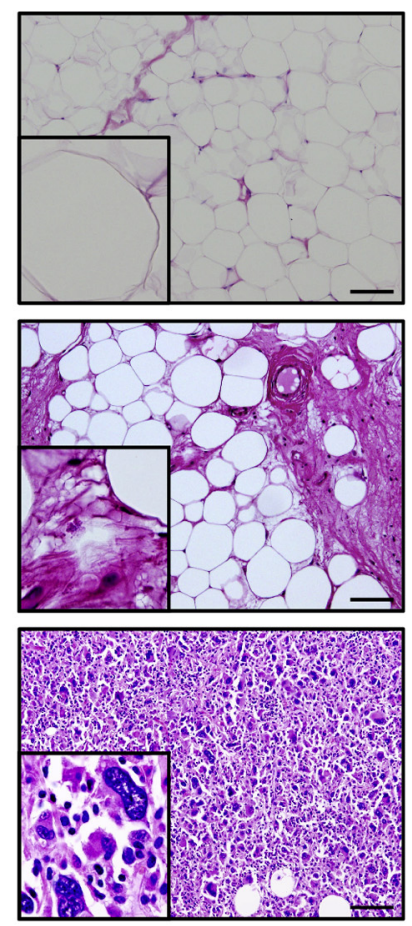

MDM2

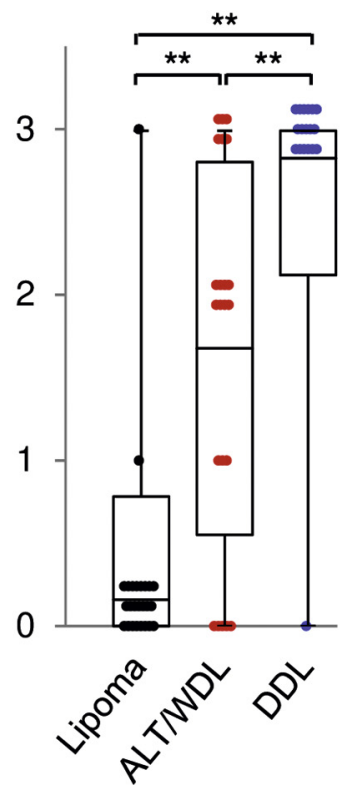

LRRC4
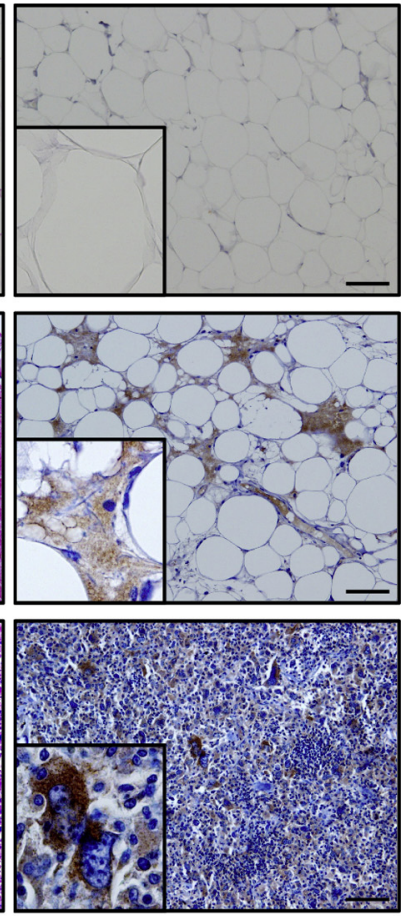

CDK4

Figure 2 Immunohistochemistry of CCDC180 and LRRC4 in surgical specimens of atypical lipomatous tumor/well-differentiated liposarcoma (ALT/WDL), dedifferentiated liposarcoma (DDL), and lipoma. A: Immunohistochemistry of CCDC180 and LRRC4. CCDC180 and LRRC4 are observed in the cytoplasm of tumor cells of ALT/WDL and $\mathrm{DDL}$, whereas both of them are almost absent in lipoma. Insets: High-magnification images. B: Immunoreactive intensities of CCDC180 and LRRC4 are significantly higher in ALT/WDL and DDL than in lipoma, similar to the known biomarkers E3-ubiquitin-protein ligase Mdm2 (MDM2) and cyclin-dependent kinase 4 (CDK4). Immunoreactive intensities of CCDC180 and MDM2 are significantly higher in DDL than in ALT/WDL. ${ }^{*} P<0.05$, ${ }^{* *} P<0.01$ (U-test). Scale bars $=50 \mu \mathrm{m}(\mathbf{A})$. Insets are approximately $50 \mu \mathrm{m}$ in width. $\mathrm{H \& E}$, hematoxylin and eosin.

marker molecules for ALT/WDL (Table 4). A known ALT/WDL marker, HMIG-C, was included in the list (Table 4). To cut the list of candidate molecules, PrognoScan, a database for meta-analysis of the prognostic value of genes (http://www.prognoscan.org), ${ }^{45}$ and The Cancer Genome
Atlas (https://cancergenome.nih.gov) were searched. Of the 15 candidates, three molecules, CCDC180, LRRC4, and chymase, were selected on the basis of biological interest. CCDC180 was associated with poor prognosis of lung adenocarcinoma, ${ }^{46}$ LRRC4 expression was increased in 
several cancers, ${ }^{47}$ and chymase played some role in tumor angiogenesis. ${ }^{48}$

Immunohistochemistry of CCDC180, LRRC4, and chymase was performed in FFPE surgical specimens from patients with ALT/WDL (22 cases) and lipoma (25 cases). In addition to ALT/WDL, 18 cases of DDL were also examined. For comparison, immunohistochemistry of known ALT/WDL markers, MDM2 and CDK4, was also performed. Immunoreactivity of CCDC180 and LRRC4 was strongly observed in the cytoplasm of tumor cells of ALT/WDL and DDL, whereas immunoreactivity of both of the molecules was almost absent or weak in lipoma (Figure 2A). The intensities of staining with antiCCDC180, anti-LRRC4, anti-MDM2, and anti-CDK4 antibodies were scored as strong $(3+)$, moderate $(2+)$, weak $(1+)$, or negative $(0)$ and are summarized in Figure $2 \mathrm{~B}$ and Supplemental Tables S3, S4, and S5. Immunoreactivity of CCDC180 and LRRC4 was significantly high in DDL, followed by ALT/WDL and lipoma, in that order (Figure 2B). In differentiation between lipoma and ALT/ WDL, a cutoff value of $2+$ produced high accuracy: sensitivity and specificity were $86.4 \%$ and $72.0 \%$, respectively, for CCDC180; they were $63.6 \%$ and $96.0 \%$, respectively, for LRRC4; they were $63.6 \%$ and $96.0 \%$, respectively, for MDM2; and they were $81.8 \%$ and $88.0 \%$, respectively, for CDK4. Considering the combination of positivity of the four molecules, CCDC180, LRRC4, MDM2, and CDK4, the highest accuracy was obtained when any of the three markers was positive (Table 5). These results indicate that a panel of multiple markers improved the accuracy compared with that of a single marker or a panel of MDM2 and CDK4. Neither the expression of CCDC180 nor that of LRRC4 was correlated with age, sex, location, or tumor size (Supplemental Table S6). The number of chymase-immunopositive cells was slightly larger in ALT/WDL than in lipoma, although antichymase antibody stained not tumor cells but mast cell-like blood cells (data not shown). These results indicated that, among the candidate molecules, CCDC180 and LRRC4 are useful markers to distinguish ALT/WDL from lipoma.
Candidate Marker Molecules Contribute to Malignant Potentials and Apoptosis Resistance in Liposarcoma Cells

Next, cell biological methods were used to further examine the expression of CCDC180 and LRRC4 in ATL/WDL. In cultured human liposarcoma cell lines SW872 (derived from unclassified liposarcoma) and 93T449 (derived from WDL), protein expression of CCDC180 and LRRC4 was confirmed by Western blot analysis (Figure 3A).

To determine whether CCDC180 expression and LRRC4 expression have a role in malignant potentials, CCDC180 and LRRC4 expression was knocked down independently and their effect was evaluated. CCDC180specific siRNAs were used, and they effectively reduced CCDC180 expression in protein levels in 93T449 cells (Figure 3A). In a WST-8 cell proliferation assay, the percentage of proliferative cells in CCDC180 knockdown (KD) cells was significantly lower than that in control cells $(P<0.01)$ (Figure 3B). In a colony-forming assay, the number of colonies in CCDC180 KD cells was significantly smaller than that in control cells $(P<0.05)$ (Figure 3D). In Ki-67 labeling analysis, the percentage of Ki-67-positive cells was significantly lower in CCDC180 KD cells than in control cells $(P<0.01)$ (Figure 3F). KD of LRRC4 showed an effect similar to that of CCDC180 in the WST-8 assay, colony-forming assay, and $\mathrm{Ki}-67$ labeling analysis $(P<0.01)$ (Figure 3, C, E, and G). These results indicate that the expression levels of CCDC180 and LRRC4 modulate the proliferation of liposarcoma cells.

In a migration assay and an invasion assay, the percentages of migrating and invasive cells were significantly lower in CCDC180 KD cells than in control cells ( $P<0.05$ and $P<0.01$, respectively) (Figure 4 , A and B), indicating that $\mathrm{CCDC} 180$ expression contributes to cell migration and invasion. Knockdown of LRRC4 had different effects from those of knockdown of CCDC180 in those assays: the number of migrating cells was not affected by LRRC4 KD (Supplemental Figure S2A), and

Table 5 Sensitivity and Specificity of a Single Marker or Multiple Markers in Immunohistochemistry

\begin{tabular}{|c|c|c|c|c|c|c|}
\hline Marker & Lipoma $(n=25)$ & ALT/WDL $(n=22)$ & Sensitivity, \% & Specificity, \% & PPV, \% & NPV, \% \\
\hline $\mathrm{MDM2}^{+}$ & 1 & 14 & 63.6 & 96.0 & 93.3 & 75.0 \\
\hline $\mathrm{CDK}_{4}^{+}$ & 3 & 18 & 81.8 & 88.0 & 85.7 & 84.6 \\
\hline $\operatorname{CCDC} 180^{+}$ & 7 & 19 & 86.4 & 72.0 & 73.1 & 85.7 \\
\hline $\mathrm{LRRC}^{+}$ & 1 & 14 & 63.6 & 96.0 & 93.3 & 75.0 \\
\hline $\mathrm{MDM}^{+} / \mathrm{CDK}^{+}{ }^{+}$ & 0 & 12 & 54.5 & 100.0 & 100.0 & 71.4 \\
\hline $\mathrm{CCDC} 180^{+} / \mathrm{LRRC}^{+}$ & 1 & 13 & 59.1 & 96.0 & 92.9 & 72.7 \\
\hline All positive & 0 & 9 & 40.9 & 100.0 & 100.0 & 65.8 \\
\hline
\end{tabular}

ALT, atypical lipomatous tumor; CDK4, cyclin-dependent kinase 4; MDM2, E3-ubiquitin-protein ligase Mdm2; NPV, negative predictive value, PPV, positive predictive value; WDL, well-differentiated liposarcoma. 
A

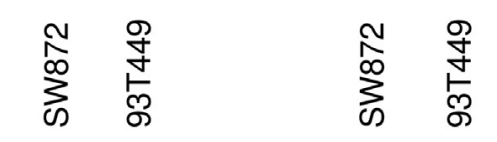

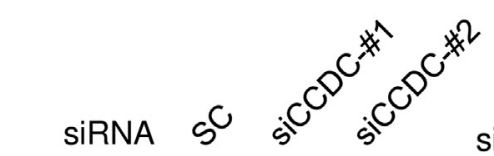<smiles>[AlH2]</smiles>

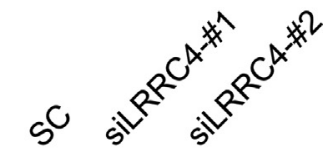
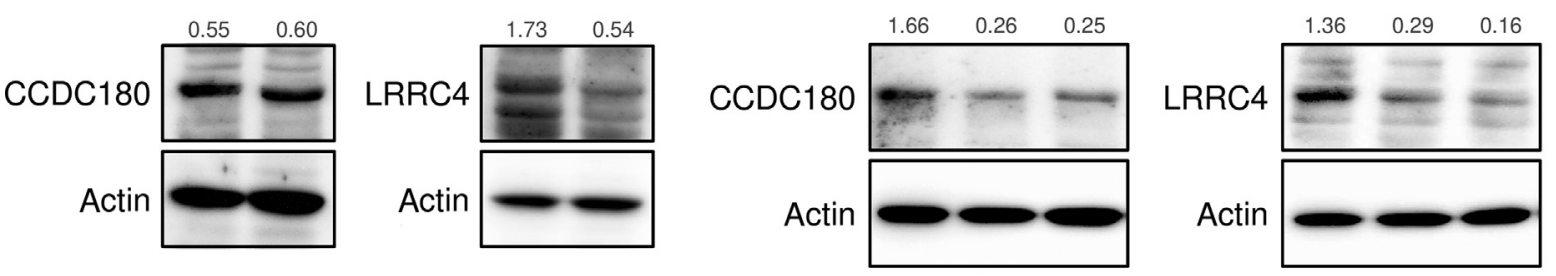

B

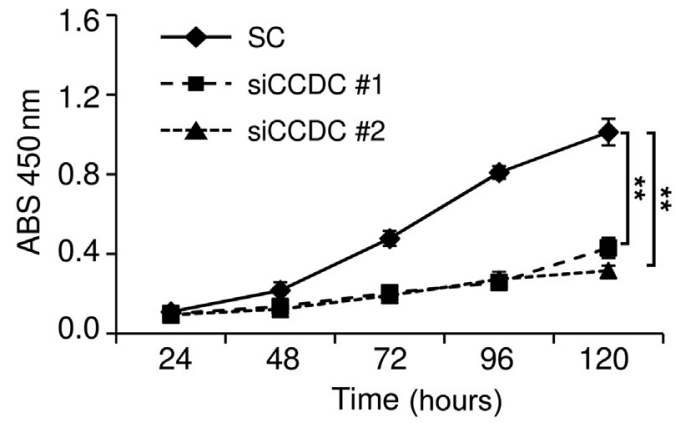

C

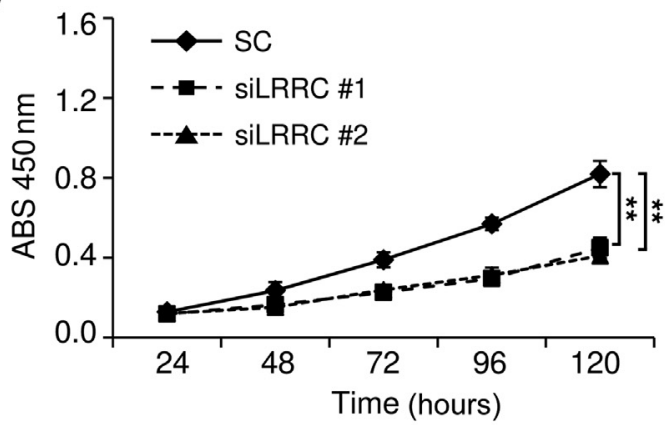

D

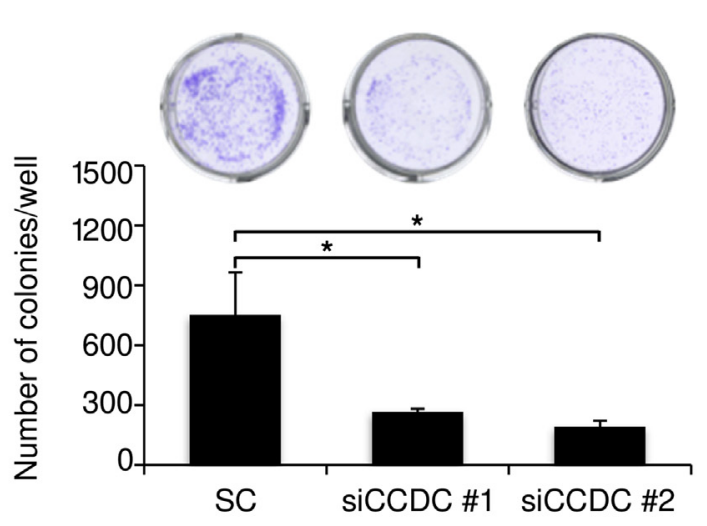

E

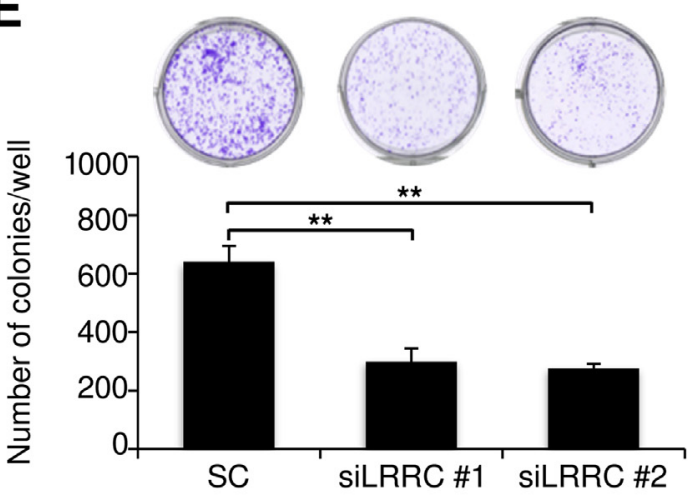

$\mathbf{F}$
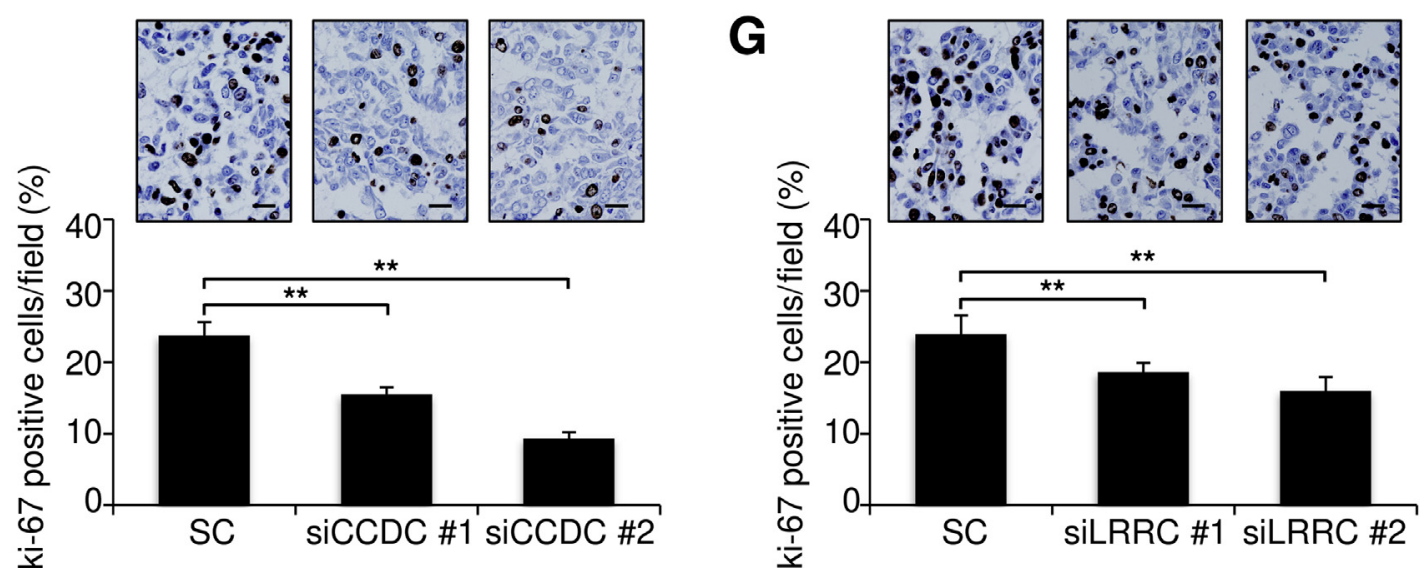

Figure 3 Knockdown (KD) of CCDC180 or LRRC4 inhibits proliferation of liposarcoma cells. A: Expression of CCDC180 or LRRC4 was knocked down by transfection of gene-specific siRNAs. Western blot analysis ( $\beta$-actin used as a loading control). B-G: CCDC180 or LRRC4 KD significantly inhibits proliferation of 93T449 cells (derived from well-differentiated liposarcoma) in multiple assays, including a WST-8 assay (B and $\mathbf{C})$, a colony formation assay (D and $\mathbf{E})$, and immunostaining with anti-Ki-67 (proliferation marker) antibody ( $\mathbf{F}$ and $\mathbf{G})$. Data are expressed as means $\pm \mathrm{SD}(\mathbf{B}-\mathbf{G}) . n=5(\mathbf{B}, \mathbf{C}, \mathbf{F}$, and $\mathbf{G}) ; n=6(\mathbf{D}$ and $\mathbf{E}) .{ }^{*} P<0.05,{ }^{*} P<0.01$ (t-test). Scale bars $=10 \mu \mathrm{m}(\mathbf{F}$ and $\mathbf{G})$. Original magnification, $\times 400(\mathbf{F}$ and $\mathbf{G})$. ABS, absorbance; SC, scrambled siRNA; siCCDC, SiRNA for CCDC180; siLRRC, SiRNA for LRRC4. 

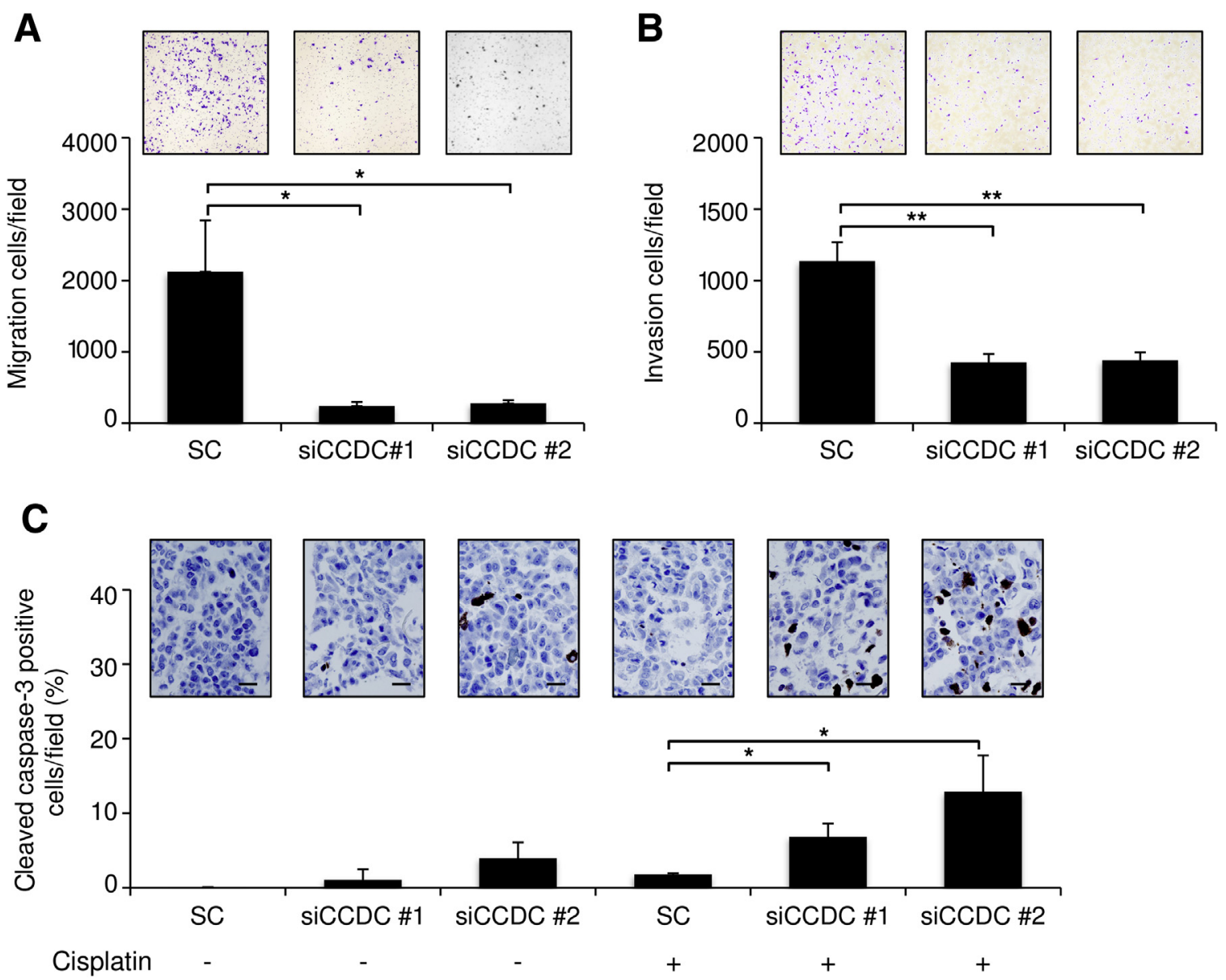

Figure 4 Knockdown (KD) of CCDC180 inhibits migration, invasion, and apoptosis resistance of liposarcoma cells. A: Transwell migration assay. CCDC180 KD significantly inhibits migration of 93T449 cells. B: Matrigel invasion assay. CCDC180 KD significantly inhibits invasion of 93 T449 cells. C: CCDC180 KD significantly increases the number of cleaved caspase-3-positive apoptotic cells induced by treatment with cisplatin $(40 \mu \mathrm{mol} / \mathrm{L}, 24 \mathrm{hours})$. Data are expressed as means \pm SD $(\mathbf{A}-\mathbf{C}) . n=3(\mathbf{A}-\mathbf{C}) .{ }^{*} P<0.05,{ }^{*} P<0.01(t$-test). Scale bars $=10 \mu \mathrm{m}(\mathbf{C})$. Original magnification: $\times 40(\mathbf{A}$ and $\mathbf{B}) ; \times 400(\mathbf{C})$. SC scrambled siRNA; SICCDC, siRNA for CCDC180.

the number of invasive cells was larger in LRRC4 KD cells than in control cells $(P<0.01)$ (Supplemental Figure S2B).

Next, the relationship between apoptosis resistance and CCDC180 and LRRC4 expression was examined. The number of cleaved caspase-3-positive cells, an indicator of apoptotic cells, was increased by knockdown of CCDC180, indicating that CCDC180 plays an antiapoptotic role in liposarcoma cells (Figure 4C). The antiapoptotic effect of CCDC180 became more obvious by treatment with cisplatin, an apoptosis-inducing agent, with the number of cleaved caspase-3-positive cells being significantly higher in $C C D C 180 \mathrm{KD}$ cells than in control cells $(P<0.05)$ (Figure $4 \mathrm{C})$. The numbers of cleaved poly (ADP-ribose) polymerase-positive cells and apoptotic bodies, downstream apoptotic indicators of cleaved caspase-3, were also significantly increased by knockdown of CCDC180 under an apoptosis-inducing condition (Supplemental Figure S3). However, knockdown of LRRC4 did not significantly alter the number of cleaved caspase-3-positive cells, even after treatment with cisplatin (Supplemental Figure S2C).

\section{Adipogenic Differentiation Suppresses Expression of CCDC180 and LRRC4 in Liposarcoma Cells}

To elucidate the molecular mechanisms responsible for expression of CCDC180 and LRRC4, 93T449 cells were chemically induced to undergo adipogenic differentiation because alteration of gene expression is frequently associated with dedifferentiation. An adipogenesis-inducing cocktail (3-isobutyl-1-methylxanthine, dexamethasone, and oleic acid) increased the number of Oil Red O-positive cells, an indicator of adipocyte differentiation, and protein expression of fatty acid-binding protein 4 , indicating that the cocktail effectively induced differentiation of the liposarcoma cells into adipocyte-like cells (Figure 5A). As expected, mRNA and protein level expression of CCDC180 and LRRC4 was decreased after adipogenic differentiation by the cocktail (Figure 5, B and C). These results suggested 
A

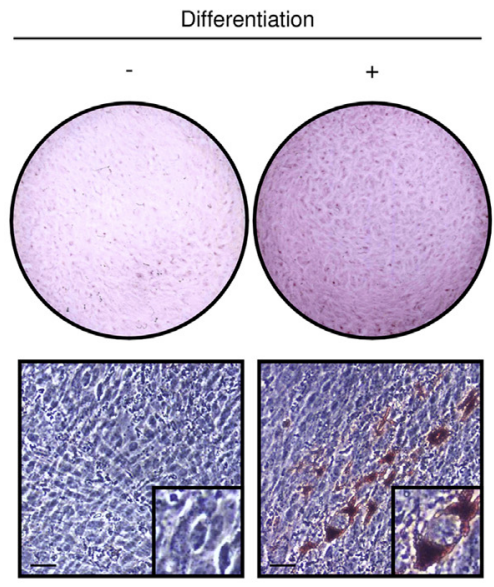

B
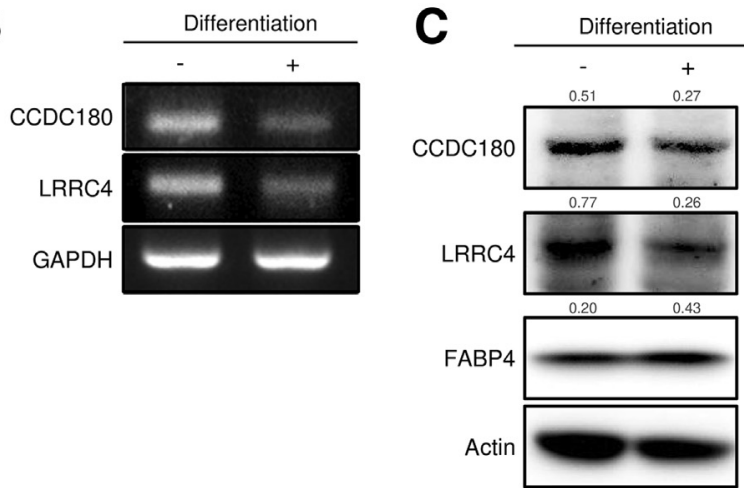

Figure 5 Adipogenic differentiation suppresses expression of CCDC180 and LRRC4 in liposarcoma cells. A: Adipogenic differentiation is induced by treatment with an adipogenesis-inducing cocktail (3-isobutyl-1methylxanthine, dexamethasone, and oleic acid). 0il Red 0 staining shows lipid accumulation in 93T449 cells. Top panels: Low-magnification images of whole cell culture plates. Bottom panels: High-magnification images of top panels. Insets: Magnified view of the 0il Red 0-positive cells. B and C: CCDC180 and LRRC4 are decreased after adipogenic differentiation. B and C: RTPCR (B) and Western blot analysis (C). Scale bars $=100 \mu \mathrm{m}(\mathbf{A})$. Insets are approximately $100 \mu \mathrm{m}$ in width. FABP4, fatty acid-binding protein 4; GAPDH, glyceraldehyde-3-phosphate dehydrogenase.

that overexpression of CCDC180 and LRRC4 is induced during dedifferentiation of adipocytes.

\section{Discussion}

Multiple candidate marker molecules were discovered for differentiating ALT/WDL from lipoma by using comparable proteome analysis of FFPE tissues. Uncommon molecules, LRRC4 and CCDC180, were identified as useful immunohistochemical markers for ALT/WDL. Furthermore, it was demonstrated that they contributed to malignant properties of liposarcoma cells and were up-regulated in association with dedifferentiation.

In this study, protein samples were prepared from FFPE tissues by using two different methods because complementary use of different methods has been suggested to increase proteome coverage and depth. ${ }^{39}$ A total of 605 proteins were identified by using a Qproteome extraction kit, 300 proteins were identified by using a guanidine- $\mathrm{HCl}$ extraction method, and 809 proteins were identified in total, indicating that use of the two methods provided more candidates. In Unused ProtScore of $>0.15,308$ proteins were identified by using a Qproteome extraction kit, 164 proteins were identified by using a guanidine- $\mathrm{HCl}$ extraction method, and 408 proteins were identified in total, indicating that the use of the two methods provided more candidates. The identified proteins included lipid metabolismassociated protein, fatty acid-binding protein 4, and lipid droplet-associated protein, perilipin-1, indicating that ALT/WDL and lipoma were derived from adipose tissues. $^{40-43}$ Subsequent selection of candidate marker molecules for ALT/WDL was based on the presence or absence of a protein.

Amplification of chromosome $12 q$ is a well-known marker for ALT/WDL, which is shown in $80 \%$ of cases. Amplification of $12 q 13-12 q 15$ leads to formation of a typical supernumerary ring and/or giant marker chromosomes and to gene amplification of $M D M 2, C D K 4$, and $H M G A 2$, the coding proteins of which were increased in ALT/WDL and detected by immunohistochemistry. ${ }^{16,17,19,21,22,49,50}$ One of the known marker molecules, high-mobility group protein (encoded by $H M G A 2)$, was included in the list of the consequent 15 candidates after a list of 181 unique proteins was narrowed down (Table 4). These results indicated that our analytical strategy, consisting of protein extraction from FFPE tissues, sample processing, mass spectrometry, and filtering the candidate molecules, is an appropriate strategy. In this study, other markers, MDM2 and CDK4, were not identified, possibly because of technical difficulties, such as low ionization efficiency of their fragmented peptides. Another possible explanation is that the expression level of MDM2 and CDK4 proteins may be insufficient to be detected by the matrixassisted laser desorption/ionization-time-of-flight/time-offlight analyzer because the number of MDM2-expressing cells was small in immunohistochemistry of ALT/WDL. ${ }^{19}$

A proteomics approach provided an opportunity for us to focus on three uncommon molecules, CCDC180, LRRC4, and chymase. Subsequent validation by immunohistochemistry in surgical specimens confirmed that antiCCDC180 and anti-LRRC4 antibodies clearly stained tumor cells of ALT/WDL and DDL, with a higher immunopositive rate in DDL than in ALT/WDL. Both of the antibodies can differentiate them from lipoma with high accuracy comparable to that of CDK4 and MDM2 (Figure 2). Neither the expression of CCDC180 nor that of LRRC4 was associated with any clinicopathological features in this study (Supplemental Table S6), possibly because of the insufficient sample size. Larger sample size may detect association between some clinicopathological features and expression of CCDC180 and LRRC4 in a future study.

Beyond the immunohistochemical utility, cell biological examination revealed that knockdown of CCDC180 or LRRC4 decreased malignant potentials of WDL cells, 
indicating that high expression levels of the molecules play important roles in WDL cells. Little is known about CCDC180. The CCDC180 gene is located on chromosome $9 \mathrm{q} 22$ and was originally identified as a Paget disease-sensitive gene, although its role has not been elucidated. ${ }^{51}$ This is the first study to demonstrate tumorassociated roles of CCDC180, such as cell proliferation, invasion, migration, and resistance to cisplatin-induced apoptosis (Figures 3 and 4). LRRC4 is also an uncommon molecule. The LRRC4 gene is located on chromosome $7 \mathrm{q} 31-32 .{ }^{52}$ LRRC4 is mainly expressed in brain tissue and plays tumor-suppressing roles in glioma and glioblastoma. ${ }^{53-57}$ In contrast, LRRC4 contributes to the proliferation of liposarcoma cells (Figure 3, C, E, and G). The difference in the roles of LRRC4 in liposarcoma and glioblastoma cells may depend on the presence of LRRC4 in their parental nonneoplastic tissues: LRRC4 was expressed in the brain but not in nonneoplastic adipose tissue (data not shown).

More important, the expression of CCDC180 and LRRC4 was reduced by induction of adipocyte differentiation in WDL cells, suggesting that their high expression in ALT/ WDL is not an instance of chance but reflects dedifferentiation during tumor development. Furthermore, the immunohistochemical analysis showed that immunoreactive intensities of the two molecules were higher in DDL than in ALT/WDL, especially for CCDC180, with a significant difference, suggesting that the expression level of the two molecules is associated with adipocyte differentiation. CCDC180 and LRRC4 may contribute to malignant potentials in cooperation with other molecules that are induced in association with adipocyte dedifferentiation, such as CCAAT/enhancer-binding protein $\alpha$ and peroxisome proliferator-activated receptor. ${ }^{58-61} \mathrm{NF}-\mathrm{\kappa B}$ signaling may also play some roles in malignant potentials of liposarcoma cells because NF- $\mathrm{KB}$ signaling generally works in opposition to peroxisome proliferator-activated receptor activation in various cancers ${ }^{62,63}$ and was reported to be regulated by LRRC4. ${ }^{64}$ These findings provide a new insight into an understanding of the roles and regulation of CCDC180 and LRRC4 in malignancies. For a better understanding of the role of the molecules, the signaling pathways responsible for malignant properties should be analyzed in a future study.

In conclusion, we identified LRRC4 and CCDC180 as novel immunohistochemical markers for differentiating ALT/WDL and showed and they contributed to malignant potentials of WDL cells. These results suggested that the molecules are potential therapeutic targets of liposarcoma. Proteome analysis using a standard stock of FFPE tissues can reveal novel biomarkers for various diseases, which contributes to the progress of molecular pathology.

\section{Acknowledgment}

We thank Yui Kawami for technical assistance with the experiments.

\section{Supplemental Data}

Supplemental material for this article can be found at https://doi.org/10.1016/j.ajpath.2019.01.013.

\section{References}

1. Voshol H, Brendlen N, Müller D, Inverardi B, Augustin A, Pally C, Wieczorek G, Morris RE, Raulf F, van Oostrum J: Evaluation of biomarker discovery approaches to detect protein biomarkers of acute renal allograft rejection. J Proteome Res 2005, 4:1192-1199

2. Okamura N, Masuda T, Gotoh A, Shirakawa T, Terao S, Kaneko N, Suganuma K, Watanabe M, Matsubara T, Seto R, Matsumoto J, Kawakami M, Yamamori M, Nakamura T, Yagami T, Sakaeda T, Fujisawa M, Nishimura O, Okumura K: Quantitative proteomic analysis to discover potential diagnostic markers and therapeutic targets in human renal cell carcinoma. Proteomics 2008, 8: 3194-3203

3. Liu YF, Xiao ZQ, Li MX, Li MY, Zhang PF, Li C, Li F, Chen YH, Yi H, Yao HX, Chen ZC: Quantitative proteome analysis reveals annexin $\mathrm{A} 3$ as a novel biomarker in lung adenocarcinoma. J Pathol 2009, 217:54-64

4. Pitteri SJ, Amon LM, Busald Buson T, Zhang Y, Johnson MM, Chin A, Kennedy J, Wong CH, Zhang Q, Wang H, Lampe PD, Prentice RL, McIntosh MW, Hanash SM, Li CI: Detection of elevated plasma levels of epidermal growth factor receptor before breast cancer diagnosis among hormone therapy users. Cancer Res 2010, 70: 8598-8606

5. Aebersold R, Mann M: Mass-spectrometric exploration of proteome structure and function. Nature 2016, 537:347-355

6. Dabbs DJ: Diagnostic Immunohistochemistry: Theranostic and Genomic Applications. ed 3. Philadelphia, PA, Saunders, 2010. pp. 1-41

7. Dietel $M$, Jöhrens $K$, Laffert $M V$, Hummel $M$, Bläker $H$, Pfitzner BM, Lehmann A, Denkert C, Darb-Esfahani S, Lenze D, Heppner FL, Koch A, Sers C, Klauschen F, Anagnostopoulos I: A 2015 update on predictive molecular pathology and its role in targeted cancer therapy: a review focussing on clinical relevance. Cancer Gene Ther 2015, 22:417-430

8. Ross JS, Gay LM, Wang K, Ali SM, Chumsri S, Elvin JA, Bose R, Vergilio JA, Suh J, Yelensky R, Lipson D, Chmielecki J, Waintraub S, Leyland-Jones B, Miller VA, Stphens PJ: Nonamplification ERBB2 genomic alterations in 5605 cases of recurrent and metastatic breast cancer: an emerging opportunity for anti-HER2 targeted therapies. Cancer 2016, 122:2654-2662

9. Maes E, Broeckx V, Mertens I, Sagaert X, Prenen H, Landuyt B, Schoofs L: Analysis of the formalin-fixed paraffin-embedded tissue proteome: pitfalls, challenges, and future prospectives. Amino Acids 2013, 45:205-218

10. Gustafsson OJ, Arentz G, Hoffmann P: Proteomic developments in the analysis of formalin-fixed tissue. Biochim Biophys Acta 2015, 1854:559-580

11. Luebker SA, Koepsell SA: Optimization of urea based protein extraction from formalin-fixed paraffin-embedded tissue for shotgun proteomics. Int J Proteomics 2016, 2016:4324987

12. Naidoo K, Jones R, Dmitrovic B, Wijesuriya N, Kocher H, Hart IR, Crnogorac-Jurcevic T: Proteome of formalin-fixed paraffin-embedded pancreatic ductal adenocarcinoma and lymph node metastases. J Pathol 2012, 226:756-763

13. Bauden M, Kristl T, Andersson R, Marko-Varga G, Ansari D: Characterization of histone-related chemical modifications in formalin-fixed paraffin-embedded and fresh-frozen human pancreatic cancer xenografts using LC-MS/MS. Lab Invest 2017, 97:279-288

14. Hayashi J, Kihara M, Kato H, Nishimura T: A proteomic profile of synoviocyte lesions microdissected from formalin-fixed paraffin- 
embedded synovial tissues of rheumatoid arthritis. Clin Proteomics $2015,12: 20$

15. Yamamoto T, Kudo M, Peng WX, Takata H, Takakura H, Teduka K, Fujii T, Mitamura K, Taga A, Uchida E, Naito Z: Identification of aldolase $\mathrm{A}$ as a potential diagnostic biomarker for colorectal cancer based on proteomic analysis using formalin-fixed paraffin-embedded tissue. Tumor Biol 2016, 37:13595-13606

16. Fletcher CD, Unni KK, Mertens F: WHO Classification of Tumors of Soft Tissue and Bone. ed 4. Lyon, France, IARC Press, 2013

17. Dei Tos AP, Doglioni C, Piccinin S, Sciot R, Furlanetto A, Boiocchi M, Dal Cin P, Maestro R, Fletcher CD, Tallini G: Coordinated expression and amplification of the MDM2, CDK4, and HMGI-C genes in atypical lipomatous tumours. J Pathol 2000, 190: $531-536$

18. Hostein I, Pelmus M, Aurias A, Pedeutour F, Mathoulin-Pélissier S, Coindre JM: Evaluation of MDM2 and CDK4 amplification by realtime PCR on paraffin wax-embedded material: a potential tool for the diagnosis of atypical lipomatous tumours/well-differentiated liposarcomas. J Pathol 2004, 202:95-102

19. Thway K, Flora R, Shah C, Olmos D, Fisher C: Diagnostic utility of p16, CDK4, and MDM2 as an immunohistochemical panel in distinguishing well-differentiated and dedifferentiated liposarcomas from other adipocytic tumors. Am J Surg Pathol 2012, 36:462-469

20. Ware PL, Snow AN, Gvalani M, Pettenati MJ, Qasem SA: MDM2 copy numbers in well-differentiated and dedifferentiated liposarcoma: characterizing progression to high-grade tumors. Am J Clin Pathol 2014, 141:334-341

21. Saâda-Bouzid E, Burel-Vandenbos F, Ranchère-Vince D, BirtwislePeyrottes I, Chetaille B, Bouvier C, Château MC, Peoc'h M, Battistella M, Bazin A, Gal J, Michiels JF, Coindre JM, Pedeutour F, Bianchini L: Prognostic value of HMGA2, CDK4, and JUN amplification in well-differentiated and dedifferentiated liposarcomas. Mod Pathol 2015, 28:1404-1414

22. Clay MR, Martinez AP, Weiss SW, Edgar MA: MDM2 and CDK4 immunohistochemistry: should it be used in problematic differentiated lipomatous tumors? a new perspective. Am J Surg Pathol 2016, 40:1647-1652

23. Paulo JA, Lee LS, Banks PA, Steen H, Conwell DL: Proteomic analysis of formalin-fixed paraffin-embedded pancreatic tissue using liquid chromatography tandem mass spectrometry. Pancreas 2012, 41:175-185

24. Shah SJ, Yu KH, Sangar V, Parry SI, Blair IA: Identification and quantification of preterm birth biomarkers in human cervicovaginal fluid by liquid chromatography/tandem mass spectrometry. J Proteome Res 2009, 8:2407-2417

25. Oki G, Wada T, Iba K, Aiki H, Sasaki K, Imai S, Sohma H, Matsumoto K, Yamaguchi M, Fujimiya M, Yamashita T, Kokai Y: Metallothionein deficiency in the injured peripheral nerves of complex regional pain syndrome as revealed by proteomics. Pain 2012 , 153:532-539

26. Shevchenko A, Jensen ON, Podtelejnikov AV, Sagliocco F, Wilm M, Vorm O, Mortensen P, Shevchenko A, Boucherie H, Mann M: Linking genome and proteome by mass spectrometry: large-scale identification of yeast proteins from two dimensional gels. Proc Natl Acad Sci U S A 1996, 93:14440-14445

27. Shilov IV, Seymour SL, Patel AA, Loboda A, Tang WH, Keating SP, Hunter CL, Nuwaysir LM, Schaeffer DA: The Paragon algorithm, a next generation search engine that uses sequence temperature values and feature probabilities to identify peptides from tandem mass spectra. Mol Cell Proteomics 2007, 6:1638-1655

28. Akimoto T, Takasawa A, Murata M, Kojima Y, Takasawa K, Nojima M, Aoyama T, Hiratsuka Y, Ono Y, Tanaka S, Osanai M, Hasegawa T, Saito T, Sawada N: Analysis of the expression and localization of tight junction transmembrane proteins, claudin- $1,-4$, -7 , occludin and JAM-A, in human cervical adenocarcinoma. Histol Histopathol 2016, 31:921-931
29. Ueda A, Takasawa A, Akimoto T, Takasawa K, Aoyama T, Ino Y, Nojima M, Ono Y, Murata M, Osanai M, Hasegawa T, Saito T, Sawada N: Prognostic significance of the co-expression of EGFR and HER2 in adenocarcinoma of the uterine cervix. PLoS One 2017, 12: e0184123

30. Keira Y, Takasawa A, Murata M, Nojima M, Takasawa K, Ogino J, Higashiura Y, Sasaki A, Kimura Y, Mizuguchi T, Tanaka S, Hirata K, Sawada N, Hasegawa T: An immunohistochemical marker panel including claudin-18, maspin, and p53 improves diagnostic accuracy of bile duct neoplasms in surgical and presurgical biopsy specimens. Virchows Arch 2015, 466:265-277

31. Aoyama T, Takasawa A, Murata M, Osanai M, Takano K, Hasagawa T, Sawada N: Immunoreactivity patterns of tight junction proteins are useful for differential diagnosis of human salivary gland tumors. Med Mol Morphol 2019, 52:23-35

32. Serlachius M, Andersson LC: Upregulated expression of stanniocalcin-1 during adipogenesis. Exp Cell Res 2004, 296: $256-264$

33. Takasawa A, Murata M, Takasawa K, Ono Y, Osanai M, Tanaka S, Nojima M, Kono T, Hirata K, Kojima T, Sawada N: Nuclear localization of tricellulin promotes the oncogenic property of pancreatic cancer. Sci Rep 2016, 6:33582

34. Takasawa K, Takasawa A, Osanai M, Aoyama T, Ono Y, Kono T, Hirohashi Y, Murata M, Sawada N: Claudin-18 coupled with EGFR/ERK signaling contributes to the malignant potentials of bile duct cancer. Cancer Lett 2017, 403:66-73

35. Schneider CA, Rasband WS, Eliceiri KW: NIH Image to ImageJ: 25 years of image analysis. Nat Methods 2012, 9:671-675

36. Akimoto T, Takasawa A, Takasawa K, Aoyama T, Murata M, Osanai M, Saito T, Sawada N: Estrogen/GPR30 signaling contributes to the malignant potentials of ER-negative cervical adenocarcinoma via regulation of claudin-1 expression. Neoplasia 2018, 20: $1083-1093$

37. Magara K, Takasawa A, Osanai M, Ota M, Tagami Y, Ono Y, Takasawa K, Murata M, Hirohashi Y, Miyajima M, Yamada G, Hasegawa T, Sawada N: Elevated expression of JAM-A promotes neoplastic properties of lung adenocarcinoma. Cancer Sci 2017, 108: 2306-2314

38. Kanda Y: Investigation of the freely available easy-to-use software 'EZR' for medical statistics. Bone Marrow Transplant 2013, 48:452-458

39. Tanca A, Abbondio M, Pisanu S, Pagnozzi D, Uzzau S, Addis MF: Critical comparison of sample preparation strategies for shotgun proteomic analysis of formalin-fixed, paraffin-embedded samples: insights from liver tissue. Clin Proteomics 2014, 11:28

40. Greenberg AS, Egan JJ, Wek SA, Garty NB, Blanchette-Mackie EJ, Londos C: Perilipin, a major hormonally regulated adipocyte-specific phosphoprotein associated with the periphery of lipid storage droplets. J Biol Chem 1991, 266:11341-11346

41. Brasaemle DL: Thematic review series: adipocyte biology: the perilipin family of structural lipid droplet proteins: stabilization of lipid droplets and control of lipolysis. J Lipid Res 2007, 48: 2547-2559

42. Bickel PE, Tansey JT, Welte MA: PAT proteins, an ancient family of lipid droplet proteins that regulate cellular lipid stores. Biochim Biophys Acta 2009, 1791:419-440

43. Frühbeck G, Méndez-Giménez L, Fernández-Formoso JA, Fernández S, Rodríguez A: Regulation of adipocyte lipolysis. Nutr Res Rev 2014, 27:63-93

44. Wang J, Duncan D, Shi Z, Zhang B: WEB-based GEne SeT AnaLysis Toolkit (WebGestalt): update 2013. Nucleic Acids Res 2013, 41: W77-W83

45. Mizuno H, Kitada K, Nakai K: PrognoScan: a new database for metaanalysis of the prognostic value of genes. BMC Med Genomics 2009, 2:18

46. Qu LW, Zhou B, Wang GZ, Chen Y, Zhou GB: Genomic variations in paired normal controls for lung adenocarcinomas. Oncotarget 2017, 24:104113-104122 
47. Baty F, Facompré M, Kaiser S, Schumacher M, Pless M, Bubendorf L, Savic S, Marrer E, Budach W, Buess M, Kehren J, Tamm M, Brutsche MH: Gene profiling of clinical routine biopsies and prediction of survival in non-small cell lung cancer. Am J Respir Crit Care Med 2010, 181:181-188

48. de Souza Junior DA, Santana AC, da Silva EZ, Oliver C, Jamur MC: The role of mast cell specific chymases and tryptases in tumor angiogenesis. Biomed Res Int 2015, 2015:142359

49. Kimura H, Dobashi Y, Nojima T, Nakamura H, Yamamoto N, Tsuchiya H, Ikeda H, Sawada-Kitamura S, Oyama T, Ooi A: Utility of fluorescence in situ hybridization to detect MDM2 amplification in liposarcomas and their morphological mimics. Int J Clin Exp Pathol 2013, 6:1306-1316

50. Kammerer-Jacquet SF, Thierry S, Cabillic F, Lannes M, Burtin F, Henno S, Dugay F, Bouzillé G, Rioux-Leclercq N, BelaudRotureau MA, Stock N: Differential diagnosis of atypical lipomatous tumor/well-differentiated liposarcoma and dedifferentiated liposarcoma: utility of p16 in combination with MDM2 and CDK4 immunohistochemistry. Hum Pathol 2017, 59:34-40

51. Fei Y, Webb R, Cobb BL, Direskeneli H, Saruhan-Direskeneli G, Sawalha AH: Identification of novel genetic susceptibility loci for Behçet's disease using a genome-wide association study. Arthritis Res Ther 2009, 11:R66

52. Li P, Xu G, Li G, Wu M: Function and mechanism of tumor suppressor gene LRRC4/NGL-2. Mol Cancer 2014, 13:266

53. Zhang Q, Wang J, Fan S, Wang L, Cao L, Tang K, Peng C, Li Z, Li W, Gan K, Liu Z, Li X, Shen S, Li G: Expression and functional characterization of LRRC4, a novel brain-specific member of the LRR superfamily. FEBS Lett 2005, 579:3674-3682

54. Wu M, Gan K, Huang C, Tang Y, Chen Q, Tang K, Li X, Shen S, Li G: LRRC4 controls in vitro invasion of glioblastoma cells through inhibiting RPTP-zeta expression. J Neurooncol 2006, 80:133-142

55. Wu M, Huang C, Gan K, Huang H, Chen Q, Ouyang J, Tang Y, Li X, Yang Y, Zhou H, Zhou Y, Zeng Z, Xiao L, Li D, Tang K, Shen S, Li G: LRRC4, a putative tumor suppressor gene, requires a functional leucine-rich repeat cassette domain to inhibit proliferation of glioma cells in vitro by modulating the extracellular signal-regulated kinase/protein kinase B/nuclear factor-B pathway. Mol Biol Cell 2006, 17:3534-3542
56. Wu M, Huang C, Li X, Li X, Gan K, Chen Q, Tang Y, Tang K, Shen S, Li G: LRRC4 inhibits glioblastoma cell proliferation, migration, and angiogenesis by downregulating pleiotropic cytokine expression and responses. J Cell Physiol 2008, 214:65-74

57. Wang Z, Guo Q, Wang R, Xu G, Li P, Sun Y, She X, Liu Q, Chen Q, Yu Z, Liu C, Xiong J, Li G, Wu M: The D domain of LRRC4 anchors ERK1/2 in the cytoplasm and competitively inhibits MEK/ERK activation in glioma cells. J Hematol Oncol 2016, 9:130

58. Pérez-Mancera PA, Bermejo-Rodríguez C, Sánchez-Martín M, Abollo-Jiménez F, Pintado B, Sánchez-García I: FUS-DDIT3 prevents the development of adipocytic precursors in liposarcoma by repressing PPARgamma and C/EBPalpha and activating eIF4E. PLoS One 2008, 3:e2569

59. Iwasaki H, Ishiguro M, Nishio J, Aoki M, Yokoyama R, Yokoyama K, Taguchi K, Nabeshima K: Extensive lipoma-like changes of myxoid liposarcoma: morphologic, immunohistochemical, and molecular cytogenetic analyses. Virchows Arch 2015, 466:453-464

60. Deng P, Chen Y, Ji N, Lin Y, Yuan Q, Ye L, Chen Q: Cysteine dioxygenase type 1 promotes adipogenesis via interaction with peroxisome proliferator-activated receptor gamma. Biochem Biophys Res Commun 2015, 458:123-127

61. Wu YV, Okada T, DeCarolis P, Socci N, O'Connor R, Geha RC, Joy Somberg C, Antonescu C, Singer S: Restoration of C/EBP $\alpha$ in dedifferentiated liposarcoma induces G2/M cell cycle arrest and apoptosis. Genes Chromosomes Cancer 2012, 51:313-327

62. Vallée A, Lecarpentier Y: Crosstalk between peroxisome proliferatoractivated receptor gamma and the canonical WNT/ $\beta$-catenin pathway in chronic inflammation and oxidative stress during carcinogenesis. Front Immunol 2018, 9:745

63. Ajuwon KM, Spurlock ME: Adiponectin inhibits LPS-induced NFkappaB activation and IL-6 production and increases PPARgamma2 expression in adipocytes. Am J Physiol Regul Integr Comp Physiol 2005, 288:R1220-R1225

64. Li P, Feng J, Liu Y, Liu Q, Fan L, Liu Q, She X, Liu C, Liu T, Zhao C, Wang W, Li G, Wu M: Novel therapy for glioblastoma multiforme by restoring LRRC4 in tumor cells: LRRC4 inhibits tumor-infiltrating regulatory $\mathrm{T}$ cells by cytokine and programmed cell death 1-containing exosomes. Front Immunol 2017, 8:1748 